\title{
PERILAKU DEBITUR DALAM MENENTUKAN PEMBIAYAAN SYARIAH \\ (STUDI KASUS PADA BEBERAPA BPRS DI WILAYAH TANGERANG DAN BEKASI)
}

Oleh: Hasnil Hasyim

\begin{abstract}
Syariah banking as one of increasing financial institution is hoped to be one of the alternative solution to overcome the economic crisis in Indonesia. It is due to the fact of the bank's capability to survive during the crisis where most of the conventional banks experienced bankruptcy which was caused by the high rate of interest resulting in the liquidity weaken. The positive impact of the syariah banking existence is the effective of the intermediary function of a bank, that is financing allocation at real sektor resulting in $100 \%$ of Loan to Deposite Ratio (LDR) amount. This has a direct influence in developing the community's economy and in reducing the unemployment number. Theoritically, the high amount of LDR has a positive correlation to credit risk a research on the debtor behavior and faktor influencing them in determining the syariah financing is conducted so that the default risk can be minimize.
\end{abstract}

Key word: debitor behavior, syariah banking

\section{A. Pendahuluan}

Bank pada hakikatnya adalah lembaga keuangan intermediasi antara penabung dan investor. Tabungan hanya akan berguna bila diinvestasikan, sedangkan para penabung tidak dapat diharapkan untuk sanggup melakukannya sendiri dengan trampil dan sukses. Nasabah mau menyimpan dananya di bank karena ia percaya bahwa bank dapat memilih alternatif invesatsi yang menarik. Proses pemilihan investasi harus dilakukan dengan seksama karena kesalahan dalam pemilihan bentuk invesatsi akan membawa akibat bank tidak bisa memenuhi kewajibannya kepada para nasabah.

$$
\text { Loan Deposit Ratio (LDR) }
$$

merupakan rasio investasi portofolio suatu bank pada investasi sektor riil yang diharapkan memiliki return yang cukup tinggi. Dampak negatif dari LDR adalah resiko kredit. Hal ini akan muncul jika bank tidak bisa memperoleh kembali cicilan pokok atau bunga dari pinjaman yang diberikannya atas investasi yang dilakukan.

Jenis risiko lainnya yang sering dihadapi oleh perbankan adalah risiko likuiditas. Pemicu utama kebangkrutan yang dialami oleh bank,besar atau kecil bukanlah karena kerugian yang dideritanya melainkan lebih kepada ketidakmampuan bank memenuhi likuiditasnya. Likuiditas secara luas dapat didefinisikan sebagai kemampuan untuk memenuhi kebutuhan dana (cashflow) dengan segera dan dengan biaya yang sesuai. Likuiditas penting bagi bank untuk menjalankan transaksi bisnis sehari-hari,mengatasi kebutuhan dana yang mendesak,memuaskan permintaan nasabah terhadap para peminjam dan memberikan fleksibilitas dalam meraih kesempatan invesatsi yang lebih menarik dan menguntungkan. 


\section{B. Perumusan Masalah}

Dengan adanya perbankan syariah saat ini yang diikuti dengan tingginya LDR, secara teori akan meningkatnya risiko kredit pada pada perbankan syariah tersebut, untuk menekan risiko kredit maka perlu dilakukan kajian mengenai prilaku debitur dan faktor-faktor yang mempengaruhi debitur dalam menentukan pembiayaan syariah.

Berdasarkan pernyataan di atas, masalah yang akan diteliti adalah:

1. Bagaimana perilaku debitur dalam menentukan pola pembiayaan pada perbankan syariah?

2. Faktor-faktor apakah yang melatarbelakangi debitur dalam menentukan pola pembiayaan syariah?

\section{Tujuan penelitian}

Penelitian ini memiliki tujuan sebagai berikut:

1. Menganalisis karakteristik dan prilaku debitur dalam menentukan pembiayaan syariah berdasarkan faktor variabel-variabel bebas (usia debitur, jenis usaha, omzet penjualan, lamanya menjalankan usaha, lamanya menjadi nasabah, dan nilai pembiayaan yang diberikan pada bank).

2. Memberikan jawaban sejauh manakah signifikansi variabelvariabel yang mempengaruhi keputusan pembiayaan syariah.

\section{Metodologi Penelitian}

Penelitian ini menggunakan metode penelitian kualitatif, dari hasil data-data yang diperoleh dari bank yang berkaitan dengan debitur (data sekunder) kemudian dikuantitatifkan, yaitu ditransformasikan atau diolah dalam pendekatan ekonometri yang dikenal dengan model logit.

Pendekatan ekonometri dengan menggunakan model logit merupakan alat untuk menganalisis data-data kuantitatif dengan bantuan komputer setelah terlebih dahulu dilakukan pengkodean, verifikasi dan pengeditan sehingga keakuratan data lebih mudah dianalisis.

Untuk variabel debitur dalam menentukan pembiayaan syariah, maka penulis menentukan 7 variabel yaitu usia debitur, jenis usaha, omset penjualan, lamanya menjalankan usaha, lokasi usaha, lamanya debitur menjadi nasabah, dan nilai pembiayaan.

Setelah membuat variabel bebas di atas, maka dapat ditentukan variabel terikat sehingga dapat disimpulkan bahwa:

1. Variabel terikat

Faktor-faktor apakah seorang debitur menentukan pembiayaan syariah:

Berharga 1: Bila pilihan debitur mudharabah/musyarakah.

Berharga 0: Bila pilihan debitur murabahah/jual beli.

Dari beberapa pendefinisian di atas, maka dapat dibuat sebuah model logit, sebagai berikut:

$\mathrm{Y}=\beta 0+\beta 1 \mathrm{X} 1+\beta 2 \mathrm{X} 2+\beta 3 \mathrm{X} 3+\beta 4 \mathrm{X} 4+$ $\beta 5 \mathrm{X} 5+\beta 6 \mathrm{X} 6+\beta 7 \mathrm{X} 7$

Keterangan:

$\mathrm{Y}=$ debitur memilih produk mudharabah atau lainnya

$\mathrm{X} 1=$ usia

$\mathrm{X} 2=$ jenis usaha

$\mathrm{X} 3=$ omset penjualan $/$ bulan

$\mathrm{X} 4$ = lamanya menjalankan usaha

$\mathrm{X} 5=$ lokasi usaha

$\mathrm{X} 6$ = lamanya debitur menjadi nasabah

$\mathrm{X} 7=$ nilai pembiayaan 


\section{E. Metodologi Penelitian}

1. Metode Analisis

a. Pengujian faktor analisis

Sebelum melakukan pengolahan data dengan menggunakan metode regresi logistik, maka pengujian variabel-variabel dengan faktor analisis harus dilakukan. Pengujian faktor analisis merupakan suatu teknik statistik yang digunaan untuk mengekstrak (mereduksi) sejumlah variabel atau unit observasi yang diteliti dapat digabungkan ke dalam faktor (komponen utama) dasar yang jumlahnya lebih kecil dari sekumpulan variabel-variabel asal, tetapi masih memiliki informasi yang mendekati nilai informasi yang dibutuhkan.

Hitungan pengujian data untuk faktor analisis:

1) Sebagian besar ( $>50 \%)$ nilai matrik korelasi mempunyai nilai lebih besar dari 0,3

2) Nilai Kaiser-Meyen-Olkin (KMO) harus lebih besar dari 0,5

3) Nilai Partial Korelasi untuk setiap variabel lebih besar dari 0,5

Jika nilai Partial Korelasi suatu variabel $<0,5$ maka variabel tersebut tidak digunakan dalam faktor analisis.

4) Nilai Bartlett test of sphericity besar pada tingkat signifikan kecil

Jika syarat 1,2, dan 4 terpenuhi, maka data yang digunakan dapat dilanjutkan untuk dihitung dengan menggunakan metode prinsipal komponen.

b. Model Regresi Logistik

Bentuk model regresi logistik menurut Nachrowi, ${ }^{1}$ adalah sebagai berikut:

* Dosen Tetap Prodi. Perbankan Syari'ah STAI Al-Hidayah Bogor

1 Djalal Nachrowi, Penggunaan Teknik Ekonometri, Jakarta, Rajawali Press, 2002, hlm. 259.
$\mathrm{E}(\mathrm{Y}=1 / \mathrm{xi})=\pi(\mathrm{xi})=[\operatorname{Exp}(\beta 0+\beta 1 \mathrm{X} 1+\beta 2 \mathrm{X} 2+\cdots$ $+\beta \mathrm{KXK})]$ atau $1+\exp (\beta 0+\beta 1 \times 1+\beta 2 \times 2 \ldots+\beta \mathrm{kxk})$

Dimana $\mathrm{x} 1$ sampai dengan xk adalah peubah penjelas ke-1 sampai dengan ke-k.

Untuk memperoleh fungsi yang linier $\mathrm{g}(\mathrm{x})$, model tersebut biasanya ditransformasikan menjadi bentuk tertentu yang dikenal dengan nama transformasi logit, menurut Nachrowi, ${ }^{2}$ adalah sebagai berikut:

$$
\begin{aligned}
g(x)=\ln \quad \frac{\pi(\mathrm{x})}{1-\pi(\mathrm{x})} \\
\\
=\beta 0+\beta 1 \mathrm{X} 1+\beta 2 \mathrm{X} 2+. .+\beta \mathrm{KXK}
\end{aligned}
$$

1) Pengujian signifikansi model dan parameter.

Pada model regresi logistik dengan prinsip yang sama uji signifikan dilakukan terhadap fungsi logaritma likelihood, biasanya dikenal dengan uji nisbah kemungkinan (likelihood ratio test). Satistik uji yang digunakan adalah $\mathrm{G}=-2 \mathrm{ln}$ (likelihood tanpa peubah penjelas/likelihood dengan peubah penjelas) yang mengikuti sebaran khi-kuadrat dengan derajad bebas $p$, dimana $\mathrm{p}$ adalah jumlah peubah bebas penjelas.

2) Uji signifikan lain yang dilakukan adalah uji wald (wald test), uji ini digunakan untuk memeriksa keberartian beta secara parsial, yaitu membandingkan dugaan beta dengan penduga ragamnya.

$\mathrm{HO}$ : beta $\mathrm{j}$ lawan $\mathrm{Hi}$ : beta $\mathrm{j}$ tidak sama dengan 0 dengan statistik ujinya $\mathrm{Q}=$ (beta $\mathrm{j} 2 / \mathrm{s} 2$ ) yang mengikuti sebaran khi-kuadrat dengan derajat bebas satu.

3) Interpretasi koefisien model regresi logistik

Interpretasi koefisien-koefisien dalam model regresi logistik dilakukan

2 Ibid., hlm. 259. 
dalam bentuk odds ratio (perbandingan resiko) atau dalam adjusted probability (probabilitas terjadi). Odds ratio didefinisikan sebagai:

$$
\frac{P}{P-1}(\text { Risiko })
$$

Dimana $\mathrm{p}$ menyatakan probabilitas sukses (terjadinya peristiwa $\mathrm{y}=1$ ) dan $1-p$ menyatakan probabilitas gagal (terjadinya peristiwa $\mathrm{y}=0$ ).

Odds ratio (perbandingan resiko) adalah perbandingan nilai odds (risiko) pada dua individu A dan individu B.

Odds ratio dituliskan sebagai berikut:

$$
\mathrm{y}=\frac{\mathrm{P}(\mathrm{XA}) / 1-\mathrm{P}(\mathrm{XA})}{\mathrm{P}(\mathrm{XB}) / 1-\mathrm{p}(\mathrm{XB})}
$$

$\mathrm{XA}=$ karakteristik individu $\mathrm{A}$

$\mathrm{XB}=$ karakteristik individu $\mathrm{B}$

\section{c. Teknik Pengumpulan Data}

Data yang digunakan adalah data sekunder yang berkaitan dengan prilaku debitur seperti usia, jenis usaha, omset penjualan, lamanya menjalankan usaha, lokasi usaha, lamanya berinteraksi dengan bank dan nilai pembiayaan. Adapun datadata diperoleh melalui berbagai BPRS yang berada di lokasi Ciputat, Ciledug, Tangerang dan Pondok Cabe.

Teknik pengambilan sampel dilakukan dengan cara memberikan label atau nomor pada 84 BPRS dalam bentuk kertas gulungan yang kemudian dimasukkan pada kotak dan dilakukan pengambilan secara acak sederhana (simple random sampling) dan dari kotak tersebut diambil sebanyak 4 nama BPRS secara acak sederhana sebagai objek penelitian.

Dari satu BPRS tersebut diambil 100 data yang berkaitan dengan perilaku debitur sehingga data yang diperoleh kurang lebih berjumlah 400 data debitur, kemudian data tersebut diolah pada program software computer yang dikenal dengan SPSS.

TABEL 3.1

\begin{tabular}{|l|l|c|c|c|c|c|c|}
\hline & & B & S.E & Wald & df & Sig. & Exp (B) \\
\hline Step 1 & VAR00002 & & & 2.969 & 2 & .227 & \\
\hline & VAR00002(1) & -2.144 & 1.296 & 2.738 & 1 & .098 & .117 \\
\hline & VAR00002(2) & -1.166 & 1.101 & 1.109 & 1 & .292 & .314 \\
\hline & VAR00003 & & & 1.212 & 2 & .545 & \\
\hline & VAR00003(1) & .745 & .726 & 1.052 & 1 & .305 & 2.106 \\
\hline & VAR00003(2) & .729 & .718 & 1.031 & 1 & .310 & 2.072 \\
\hline & VAR00004 & & & 7.817 & 2 & .020 & \\
\hline & VAR00004(1) & 1.849 & .790 & 5.473 & 1 & .019 & 6.353 \\
\hline & VAR00004(2) & 2.587 & 1.156 & 5.007 & 1 & .025 & 13.285 \\
\hline & VAR00005 & & & 2.609 & 2 & .271 & \\
\hline & VAR00005(1) & -1.270 & 1.264 & 1.009 & 1 & .315 & .281 \\
\hline & VAR00005(2) & -.792 & .532 & 2.219 & 1 & .136 & .453 \\
\hline & VAR00006 & & & 16.817 & 3 & .001 & \\
\hline & VAR00006(1) & 2.918 & .913 & 10.217 & 1 & .001 & 18.504 \\
\hline & VAR00006(2) & 1.692 & .605 & 7.825 & 1 & .005 & 5.430 \\
\hline & VAR00006(3) & 2.420 & .699 & 12.001 & 1 & .001 & 11.250 \\
\hline
\end{tabular}




\begin{tabular}{|l|l|c|c|c|c|c|c|}
\hline & VAR00007 & .845 & .547 & 2.391 & 1 & .122 & 2.329 \\
\hline & VAR00008 & & & 5.214 & 2 & .074 & \\
\hline & VAR00008(1) & .909 & .753 & 1.459 & 1 & .227 & 2.482 \\
\hline & VAR00008(2) & 1.753 & .774 & 5.133 & 1 & .023 & 5.771 \\
\hline & Constant & -.376 & 1.365 & .076 & 1 & .783 & .687 \\
\hline
\end{tabular}

Sumber: hasil pengolahan data diambil dari 4 BPRS

Tabel 3.1 di atas merupakan nilai estimasi, uji wald, dan nilai exp (B), yang kesemuanya merupakan bentuk model yang didapatkan. Dari tabel tersebut dapat dilihat bahwa semua koefisien variabel bebas signifikan secara statistik pada alfa $=5 \%$, kecuali koefisien pada variabel 2 (usia), variabel 3 (jenis usaha) dan variabel 5 (lamanya menjalankan usaha). Perlukah variabel tersebut dikeluarkan dari model?

Kembali pada substansi masalah yaitu ingin meneliti faktor-faktor apakah yang mempengaruhi debitur dalam menentukan pembiayaan syariah dan apakah usia, jenis usaha, lamanya menjalankan usaha juga sangat mempengaruhi kecenderungan dalam menentukan pembiayaan syariah tersebut. Jika salah satu dikeluarkan dalam model, maka kehilangan informasi. Kedua, mengingat koefisien tersebut merupakan perbandingan antara sektor jasa dan perdagangan, maka tidak mudah bagi kita untuk menentukan variabel mana yang akan dibuang. Mengeluarkan sektor jasa merupakan cerminan dari usaha debitur begitu pula sektor perdagangan.

Berdasarkan tabel di atas, maka persamaan model logistik yang didapat adalah sebagai berikut :

$\operatorname{Ln}(\mathrm{p} / 1-\mathrm{p})=-0,376-2,144$ usia $(1)$

$-1,160$ usia $(2)+0,745 \mathrm{JU}(1)+$

$0,729 \mathrm{JU}(2)+1,849$

Omset (1) $+2,587$ omset (2) 1,270 lamanya us (1) $-0,792$ lamanya us $(2)+2,918$

lok us (1) + 1,692 lok us (2) + 2,420 lok us $(3)+0,845$ lamanya menjadi nas $+0,909$ nilai pembiayaan (1) $+1,753$ nilai pembiayaan (2).

\section{Analisis dan Interpretasi Model}

Berdasarkan pada tabel diatas dan persamaan model logistik di atas, maka dapat diinterpretasikan bahwa dengan nilai intersep sebesar $-0,376$, yang berarti bahwa pada saat semua variabel 0 yaitu usia berkode 0 ( $>50$ th), jenis usaha berkode 0 (industry), omset berkode 0 ( $>51$ juta), lamanya usaha berkode 0 ( $>5$ thn) lokasi usaha berkode 0 (ruko/kantor), lamanya menjadi nasabah 0 ( $>1$ thn), dan nilai pembiayaan 0 ( $>51$ juta), maka probabilita mereka memilih pembiayaan murabahah adalah:

$\operatorname{Ln}(\mathrm{p} / 1-\mathrm{p})=-0,376$

$(\mathrm{p} / 1-\mathrm{p}) \quad=\exp -0,376$

$\mathrm{P}=\exp -0,376$ atau $1-\exp -0,376)=0,4070=40,70 \%$

1) Usia

Pada hasil penelitian di atas terlihat bahwa peluang debitur yang berusia di atas 50 tahun lebih dominan untuk memilih pembiayaan murabahah dibanding dengan debitur yang berusia dibawah 50 tahun. Pernyataan ini tidak sesuai dengan realitas yang terjadi di BPRS sehingga perlu diluruskan, sebaiknya dinyatakan bahwa peluang debitur yang berusia 30-50 tahun untuk memilih pembiayaan murabahah lebih dominan disbanding debitur yang berusia diatas 50 tahun. Hal ini dimungkinkan terjadi pada data yang diperoleh, maksudnya adalah pada saat 
debitur akan meminjam pembiayaan pada bank, maka seringkali terjadi bahwa pembiayaan tersebut ditandatangani oleh wakil peminjam yang memiliki hubungan emosional dengan pihak bank, sedangkan yang mengelola usahanya adalah pihak ketiga seperti istrinya atau keluarganya sehingga dapat dikhawatirkan terjadi kurang validnya/signifikansi dari variabel usia pada persamaan model di atas.

2) Jenis usaha

Nilai koefisien slope untuk variabel jenis usaha 1 (sektor perdagangan) adalah 0,745 . Hal ini menunjukkan bahwa peluang debitur yang bergerak pada sektor perdagangan untuk memilih pembiayaan murabahah lebih tinggi. Dengan nilai exp (B) sebesar 2,106 dapat diartikan bahwa peluang debitur yang bergerak pada sektor perdagangan untuk memilih pembiayaan murabahah lebih tinggi 2,106 kali peluang jenis usaha industri.

Pada hasil penelitian di atas terlihat bahwa peluang jenis usaha debitur yang bergerak pada sektor perdagangan lebih tinggi untuk memilih pembiayaan murabahah dibanding sektor lainnya seperti sektor jasa dan industri.

\section{3) Omset penjualan}

Nilai koefisien slope untuk omset penjualan 1 di bawah 20 juta ( $<20$ juta) adalah 1,849. Hal ini menunjukkan bahwa peluang kelompok debitur yang mempunyai omset penjualan di bawah 20 juta untuk memilih pembiayaan murabahah lebih tinggi dibandingkan dengan kelompok debitur yang beromset penjualan diatas 50 juta/bulan. Dengan nilai exp (B) sebesar 6,353 dapat diartikan bahwa peluang kelompok debitur yang mempunyai omset penjualan di bawah 20 juta untuk memilih pembiayaan murabahah lebih tinggi 6,353 kali dibandingkan dengan kelompok debitur yang mempunyai omset diatas 50 juta.

Hasil penelitian di atas menunjukkan bahwa debitur yang memiliki omset penjualan/bulan sekitar 20-50 juta memiliki peluang yang lebih tinggi untuk memilih pembiayaan murabahah di banding debitur yang memiliki omset penjualan di bawah 20 juta dan diatas 50 juta.

4) Lamanya menjalankan usaha

Nilai koefisien slope untuk lamanya menjalankan usaha (1) yaitu kurang dari 2 tahun adalah -1,270. Hal ini menunjukkan bahwa peluang yang menjalankan usahanya kurang dari 2 tahun untuk memilih pembiayaan murabahah lebih kecil dibandingkan kelompok debitur yang menjalankan usahanya di atas 5 tahun. Dengan nilai exp (B) sebesar 0,281 dapat diartikan bahwa peluang kelompok debitur yang menjalankan usahanya kurang dari 2 tahun lebih kecil 0,281 kali di banding kelompok debitur yang menjalan usahanya lebih dari 5 tahun.

Dari hasil penelitian di atas dapat disimpulkan bahwa debitur yang menjalankan usahanya lebih dari 5 tahun, peluang untuk memilih pembiayaan murabahah lebih tinggi dibanding debitur yang menjalankan usahanya kurang dari 2 tahun. Hal ini sesuai dengan aturan main yang terdapat di BPRS yaitu minimal lamanya usaha debitur 2 tahun.

5) Lokasi usaha.

Nilai koefisien slope untuk lokasi usaha 1, yaitu debitur yang menjalankan usahanya di pasar sebesar 2,918 yang berarti bahwa debitur yang menjalankan usahanya di pasar lebih tinggi untuk memilih pembiayaan murabahah dengan niali exp (B) sebesar 18,504 menunjukkan bahwa peluang debitur yang berlokasi usaha di pasar lebih tinggi 18,504 kali di 
banding debitur yang berlokasi di ruko/kantor, rumah penduduk, dan di pinggir jalan.

6) Lamanya menjadi nasabah

Lamanya menjadi nasabah dan nilai pembiayaan merupakan proxy (pendekatan) kepercayaan pihak perbankan kepada nasabah dan merupakan korelasi positif dengan tingkat kepercayaan, artinya adalah pada saat nasabah cukup lama berinteraksi dengan bank dan nilai pembiayaan yang diberikan cukup tinggi maka tingkat kepercayaan makin tinggi pula, begitu pula sebaliknya dan dapat berpengaruh langsung pada pembiayaan yang diberikan.

Nilai koefisien slope untuk variabel lamanya menjadi nasabah sebesar 0,845 dengan nilai exp (B) sebesar 2,329. Hal ini menunjukkan peluang kelompok nasabah yang berinteraksi dengan bank selama kuran dari 1 tahun lebih dominan untuk memilih pembiayaan murabahah sebesar 2,329 kali di banding pada kelompok nasabah yang berinteraksi pada bank lebih dari 1 tahun.

7) Nilai pembiayaan

Nilai koefisien pada nilai pembiayaan 1 ( $<10$ juta) sebesar 0,909 dengan nilai exp (B) 2,482, hal ini menunjukkan bahwa peluang kelompok debitur yang diberikan pinjaman kurang dari 10 juta lebih dominan 2,482 kali dibanding dengan kelompok debitur yang diberi pinjaman di atas 50 juta.

Hasil penelitian di atas menunjukkan bahwa debitur yang diberikan pinjaman sekitar 10-25 juta memiliki peluang lebih tinggi dibandingkan dengan debitur yang diberikan pinjaman dibawah 10 juta dan di atas 25 juta. Hal ini sesuai dengan regulasi Bank Indonesia yang ditetapkan bahwa BPRS saat ini mengenai plafond pembiayaan yang diberikan kepada nasabah disesuaikan dengan aset yang dimiliki BPRS tersebut.

\section{G. Penutup}

1. Kesimpulan

Hasil penelitian ditujukan untuk memberikan jawaban, faktor-faktor apakah yang mempengaruhi debitur dalam menentukan pembiayaan syariah? Dari hasil penelitian dapat disimpulkan bahwa debitur yang bergerak di sektor perdagangan, yang memiliki omset penjualan sekitar 20-50 juta/bulan, berlokasi usaha di pasar, yang menjalankan usahanya lebih dari 2 tahun, debitur yang menjadi nasabah bank selama 1 tahun dan nilai pembiayaan yang diberikan pada bank 10-25 juta adalah lebih dominan dalam menentukan pembiayaan murabahah.

\section{Saran}

Perbankan syariah dalam hal ini BPRS hendaknya lebih memperhatikan pembiayaan syariah kepada debitur yang bergerak pada sektor industry kecil dan menengah. Dari 3 jenis usaha yaitu sektor perdagangan, sektor jasa, dan sektor industri kecil, dan hasil penelitian menunjukkan sektor perdagangan lebih dominan dalam pembiayaan murabahah, maka BPRS diharapkan dapat memberikan porsi yang feasible kepada sektor industri kecil dan menengah karena dampaknya lebih menyentuh pengusaha kecil yang secara langsung berdampak positif pada peningkatan perekonomian masyarakat serta mengurangi pengangguran.

\section{Keterbatasan Penelitian}

Di antara 7 variabel yang mempengaruhi debitur dalam menentukan pola pembiayaan syariah di antaranya usia, jenis usaha, omset penjualan, lamanya menjalankan usaha, lokasi usaha, lamanya menjadi nasabah, dan nilai pembiayaan yang 
diberikan bank maka dimungkinkan adanya variabel-variabel lain yang lebih dominan dalam menentukan pembiayan syariah.

Dalam penelitian ini menggunakan metode regresi logit, yaitu variabel terikatnya terdiri dari 2 kategorik yaitu pembiayaan murabahah atau lainnya, maka dimungkinkan untuk penelitian selanjutnya menggunakan model multinomial logistik yang mana variabel terikatnya menggunakan pilihan berganda (lebih dari 2 kategorik), sehubungan dengan makin banyaknya produk pembiayaan yang dikembangkan perbankan syariah saat ini.

\section{Daftar Pustaka}

Alquranulkarim

Antonio, Muhammad Syafi'i, Bank Syariah dari Teori ke Praktek, Jakarta, PT. Gema Insani Press, 2001. , Bank Syariah bagi Banker dan Praktisi Keuangan, Jakarta, Bank Indonesia, dan Tazkia Institute, 1999.

Arifin, Zainul, Pasar Uang dan Valuta Asing Berbasis Syariah, Jakarta, paper dipresentasikan di Bank Indonesia, 1998.

Al-Umar, Fuad dan Abdul Haq, Islamic Banking: Theory, Practice and Challenges, Oxford University Press, 1996.

AKaplan Professional Company, Study Notes for CFA Exam Book 4, The Financial Training, 2001.

Nachrowi, Djalal, Penggunaan Teknik Ekonometri, Jakarta, Rajawali Press, 2002.

Gujarati, Damodar, Ekonometri Dasar, Penerbit Erlangga Press, Jakarta, 1997. 